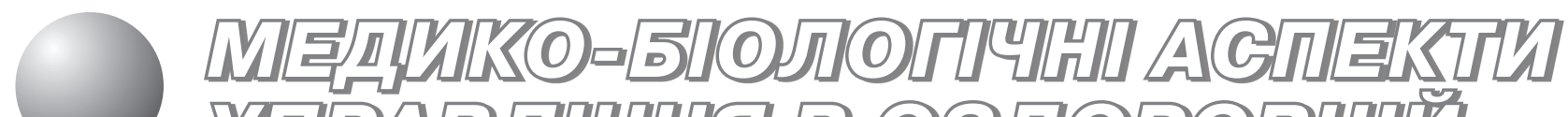

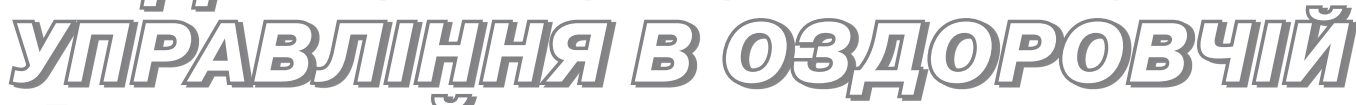

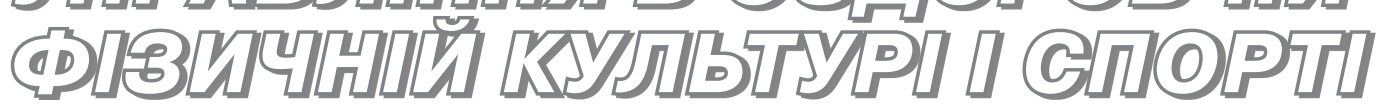

\section{Формування мотивації до занять оздоровчо-рекреаційною руховою активністю учнів старших класів Є. О. Федоренко}

Дніпропетровський державний інститут фізичної культури і спорту, Дніпропетровськ, Україна

\begin{abstract}
Резюме. Статья посвящена проблеме формирования мотивации к занятиям оздоровительно-рекреационной двигательной активностью старшеклассников, так как в последние годы прослеживается тенденция к снижению уровней здоровья и двигательной активности, к преобладанию преимущественно пассивного образа жизни школьниковстаршеклассников. В ходе исследования были определены педагогические условия для формирования мотивации учащихся старших классов к занятиям оздоровительнорекреационной двигательной активностью, которая создает основу для их активной жизни в будущем, способствующей формированию привычки и потребности в регулярных занятиях физическими упражнениями.
\end{abstract}

Ключевые слова: мотивация, старшеклассники, двигательная активность, физическая культура, здоровье.

Summary. The article is devoted to the formation of motivation of recreational pursuits recreational and physical activity high school pupils, as in recent years there has been a downward trend in the level of health, level of physical activity, mainly to the predominance of passive lifestyle, high school pupils. During the research the pedagogical conditions for motivating high school pupils to employment health and recreational physical activity, which forms the basis of their active life in the future, promotes the formation of habits and needs in regular physical exercise.

Key words: motivation, high school pupils, physical activity, physical culture, health.

Постановка проблеми. Інтерес до занять фрізичними вправами у шкільному віці проявляється не стільки в досягненні оздоровчого ефекту, скільки у задоволенні через фрізичні вправи широкого спектра потреб, спрямованих на самовираження, проведення вільного часу, відмінне самопочуття, зміну діяльності, позитивні емоції, участь в ігровій та освітній діяльності. Дану проблему можна вирішити шляхом заохочування дітей і підлітків до регулярних занять оздоровчорекреаційною руховою активністю, яка формує основу для їхнього активного життя в майбутньому $[1,3,6]$.

Великий обсяг навчального навантаження учнів старших класів призводить до систе- матичного накопичення втоми, що негативно позначається на загальному стані їхнього здоров'я $[3,5]$. Одним із шляхів підвищення ефективності системи фрізкультурного навчання, фрізкультурно-оздоровчої діяльності школярів дослідники $[2,4,5,7]$ вважають формування позитивної мотивації до занять фрізичними вправами. Тому питання про відновлення розумової та фрізичної працездатності шляхом залучення учнів старших класів до занять оздоровчо-рекреаційною руховою активністю, підтримання здоров'я та вдосконалення фрізичного розвитку стає надзвичайно актуальним.

Аналіз останніх досліджень та публікацій. Сучасні дослідження свідчать, що рухова 
активність з використанням фрізичних вправ у поєднанні $з$ раціональним харчуванням та іншими складовими здорового способу життя залишається найдієвішим засобом, що перевищує можливості традиційної медицини у зміцненні здоров'я, профрілактиці поширення захворювань [4, 7].

Важливим напрямом вирішення цієї проблеми, на думку багатьох учених [1, 2, 4, 6], $є$ виховання відповідальності в учнів за свій фрізичний стан, що, у свою чергу, зумовлює підвищення усвідомленого ставлення до виконання ними фрізичних вправ, дотримання правил особистої гігієни та раціонального харчування, загартування, активного відпочинку, що підвищить рівень їхнього фрізичного стану.

Особливої значущості набувають в останній час нові підходи до фрізичного виховання учнів старших класів, які повинні позитивно вирішувати проблему зацікавленості старшокласників до занять оздоровчо-рекреаційною руховою активністю [2, 4].

Зв язок роботи 3 науковими програмами та практичними завданнями. Роботу виконано відповідно до Зведеного плану науково-дослідної роботи на 2011-2015 рр. за напрямом 3.1 «Вдосконалення програмно-нормативних засад фрізичного виховання в навчальних закладах» (номер держреєстрації 0111U001713).

Мета дослідження - визначити педагогічні умови для фрормування мотивації учнів старших класів до занять оздоровчо-рекреаційною руховою активністю.

Результати дослідження та їх обговорення. Успішність процесу формування мотивації старшокласників до занять оздоровчо-рекреаційною руховою активністю залежить від орієнтації навчально-виховного процесу, вона має свої характерні відмінності залежно від пріоритетних завдань та особливостей організаційно-методичних умов закладу освіти. Вихідним поняттям сутності мотивації до занять оздоровчо-рекреаційною руховою активністю є основні мотиви, якими керуються старшокласники у своїх вчинках, бажаннях в умовах навчальної і позакласної фрізкультурної діяльності.

Вивчення фракторів, що впливають на формування мотивації старшокласників до занять оздоровчо-рекреаційною руховою активністю, дозволило визначити педагогічні умови, що сприятимуть формуванню бажання займатися оздоровчо-рекреаційною руховою активністю. Механізм формування такої мотивації розглядається нами як комплекс спонукань до занять фрізичними вправами.
Зважаючи на складність процесу фрормування мотивації старшокласників до занять оздоровчорекреаційною руховою активністю, його залежність від багатьох фракторів, у дослідженні запропоновано такі педагогічні умови.

1. Розширення сфрери фізкультурної діяльності учнів за рахунок активного залучення до позаурочних форм роботи, а саме занять В спортиВних секціях. Усі фрорми фрізичного виховання об'єднуються спільною метою і завданнями. Кожна з них сприяє вирішенню загальних завдань, а також специфічних. Ось чому для оптимального розв'язання всіх завдань фізичного виховання варто практикувати різноманітні фрорми занять шляхом запровадження фрізкультурно-оздоровчих заходів у режимі дня, широкого залучення учнів до занять у спортивних секціях і гуртках, популяризації додаткових факультативних занять, відродження масових спортивно-художніх свят і днів здоров'я, різноманітних змагань і конкурсів, створюючи для цього необхідні умови. Особливу увагу в позаурочних заняттях треба звертати на реалізацію школярами в повсякденному житті знань, умінь і навичок, набутих на уроках. Характерною рисою позаурочних форм занять є їхня добровільність. Тому організатори мають піклуватися про те, аби викликати в учнів зацікавлення до них. Це досягається передусім їх високою емоційністю. Дуже важливо, щоб кожен учень міг проявити себе в них незалежно від рівня своєї підготовленості.

2. ФормуВання позитиВного ставлення до занять фозичними ВпраВами, прищеплення інтересу до занять спортом. Навчальний заклад покликаний не лише гарантувати належне фрізичне виховання дітей під час навчання, а й прищеплювати звичку щоденно, протягом усього життя, виконувати фізичні вправи для активного відпочинку і зміцнення здоров'я, занять оздоровчорекреаційною руховою активністю. Необхідною умовою виховання у дітей звички систематично займатись фрізичною культурою $€$ взаємозв'язок вчителів і сім'ї. Вплив педагогів, підтриманий батьками, забезпечить необхідне фрізичне виховання і сприятиме формуванню звички до систематичних занять фрізкультурою, тобто фрізкультурної діяльності.

3. Впровадження В практику Викладання методів і засобів активізації учнів стариих класів до занять оздоровчо-рекреаційною руховою активністю. Сорормувати інтерес старшокласників до фрізичної культури можна поглибленим вивченням теоретичних знань про фрізичну культуру, які розкривають зміст, значення й основні правила занять фрізичними вправами. 
Виховання позитивного ставлення, інтересу до фрізичних вправ досягається шляхом переконливих і емоційних пояснень, використанням різноманітних заохочень, власним прикладом. Важливо також домогтися органічного поєднання рухової активності з розумовою працею.

4. Забезпечення тісного ВзаємозВ'язку фрізичного ВихоВання та профресійної орієнтації особистості старшокласникіВ, де фозкультурна діяльність - один зі способів реалізації майбутніх профресійних планів і намірів, життєВого призначення, умова успішного Виконання соціальних і профессійних фуункцій. Завдання трудового виховання вирішують питання психологічної підготовки особистості до праці, практичної підготовки старшокласників до трудової діяльності, підготовки школярів до свідомого вибору професії.

5. Озброєння знаннями з фізичної культури та формуВання настанов до Ведення здороВого способу життя, наВчання засобіВ самоконтролю та Вміння самостійно займатись фозичними Вправами. Розраховувати на успіх впровадження самостійних занять у побут учнів можна, лише озброївши їх спеціальними вміннями, які поряд зі знаннями слід формувати на кожному уроці. Потрібно навчити всіх дітей оцінювати результати самостійної роботи шляхом зіставлення досягнутого результату і запропонованого завдання. Низька оцінка діяльності має націлити учня й учителя на пошук причин невдачі і внесення коректив у подальшу роботу. Самоконтроль - це систематичні самостійні спостереження за зміною стану свого здоров'я, фрізичного розвитку та фрункціональної готовності організму в процесі занять фізичними вправами. Дані самоконтролю використовуються учнями та учителем фрізичної культури з метою регулювання тренувальних навантажень, а також об'єктивної оцінки змін фрізичного розвитку учня.

6. ЦілеспрямоВане стимулюВання актиВної фозкультурної діяльності школяріВ у Вигляді оцінок та інших заохочень. Заохочення полягають у позитивній оцінці навчальної діяльності та поведінки учнів і спрямовані на те, щоб викликати в усіх бажання до подальших досягнень, активності та зацікавленості у вивченні предмета. Основними видами заохочення є сприяння, допомога, довіра вчителя, схвалення, усна подяка, подяка в наказі по школі, похвальна грамота, почесні доручення, лист-подяка батькам, фотограорії на дошках пошани, публікації в газетах тощо. Заохочення позитивно впливає лише тоді, коли воно є адекватним, публічним і своєчасним.

7. Активне Використання міжпредметних зВ'язків для підвищення мотивації стар-
шокласникіВ до занять оздоровчо-рекреаційною руховою актиВністю як одного з компоненті८ здорољого способу життя. Набуттю знань сприяють міжпредметні зв'язки, цінність яких полягає ще й у тому, що вони $є$ хорошою основою для об'єднання дій усіх шкільних педагогів на користь масової фрізичної культури. Тут ідеться не тільки про позакласну роботу, а й про уроки з усіх навчальних дисциплін.

8. Сприяння збудженню Внутрішніх механізмів активності до фізкультурної діяльності учніВ старших класіВ для прояВу сВоїх прагнень, намагань, ВияВу ВольоВих якостей В урочній та позаурочній роботі. Це важливо при вихованні у старших учнів інтересу до занять фрізичною культурою, фрормуванні бажання активної участі в процесі фрізкультурного навчання. В старшому шкільному віці у дітей відбувається перехід від природної потреби у рухах до усвідомленої необхідності у фрізичних вправах. Такий підхід, як відомо, потребує вольових зусиль учнів, які в даному віці ще недостатньо сорормовані. Тому в практичній роботі необхідно спиратися на інтерес, який є великою рушійною силою, може значно підсилити мотиви і заохотити учнів старших класів до регулярних занять фрізичними вправами.

Висновки. Для цілеспрямованого фрормування мотивації старшокласників до регулярних занять оздоровчо-рекреаційною руховою активністю нами було розроблено та запропоновано педагогічні умови: сприяння збудженню внутрішніх механізмів активності до фрізкультурної діяльності; активне використання міжпредметних зв'язків для підвищення мотивації; цілеспрямоване стимулювання активної фрізкультурної діяльності школярів у вигляді оцінок та інших заохочень; озброєння знаннями з фрізичної культури; забезпечення тісного взаємозв'язку фрізичного виховання та професійної орієнтацієї особистості старшокласників; впровадження в практику викладання методів і засобів активізації учнів старших класів до занять оздоровчорекреаційною руховою активністю; формування позитивного ставлення до занять фрізичними вправами, прищеплення інтересу до занять спортом; розширення сорери фрізкультурної діяльності учнів за рахунок активного залучення до позаурочних форм роботи, а саме занять в спортивних секціях.

Перспективи подальших досліджень у даному напрямі. Такі перспективи пов'язані 3 визначенням шляхів формування мотивації до занять оздоровчо-рекреаційною руховою активністю учнів молодшого шкільного віку. 


\section{Література}

1. АндрєєВа О. Аналіз мотиваційних теорій у сорері оздоровчої фрізичної культури та рекреації / О. Андрєєва // Теорія і методика фріз. виховання і спорту. - 2004. № 2. - С. 81-84.

2. БезВерхня Г. В. Мотивація до занять фрізичною культурою і спортом школярів 5-11-х класів: дис. ... канд. наук з фріз. виховання і спорту: 24.00.02 / Г. В. Безверхня. - Умань: Уман. держ. пед. ун-т ім. Павла Тичини, 2004. - 258 c.

3. КоВальова Н. Технологія проектування рекреаційно-оздоровчої діяльності старшокласників / Н. Ковальова, О. Андрєєва // Теорія і методика фріз. виховання і спорту. - 2012. - № 2. - С. 29-34.

4. КруцеВич Т. Ю. Рекреація у фрізичній культурі різних груп населення / Т. Ю. Круцевич, Г.В.Безверхня. - К.: Олімп. л-ра, 2010. - 248 с.

5. Чухно П. В. Комплексный педагогический подход к формированию у школьников общеобразовательных школ положительной мотивации к систематическим занятиям физической культурой, к здоровому образу жизни / П. В. Чухно, Р. Р. Азиуллин, Е. А. Медведева // Педагогико-психол. и медико-биол. проблемы физ. культуры и спорта. - 2010. - № 3. - С. 112-118.

6. Ames C. Achivement goals, motivation climate, and motivation progress / C. Ames // Motivation in sports and exercise. Champaing IL: Human Kinetics. - 1992. - P. 161176.

7. Hodge K. Motivation in masters sport: Achievement and social goals / K. Hodge, J.B. Allen, L. Smellie / / Psychology of Sport and Exercise. - 2008. - Vol. 9. - P. 157-176.

\section{References}

1. Andreeva A. Analysis of motivational theories in improving physical education and recreation / A. Andreeva / / Theory and Methods Phys. education and sport. - 2004. N 2. - P. 81-84

2. Bezverkhnya G. V. Motivation for physical education and sports students 5-11th graders : Dissertation of the candidate of physical education and sport: 24.00.02 / G. V. Bezverkhnya / Uman State Pedagogical University. Pavla Tichinu. - Uman, 2004. - 258 s.

3. Kovalev N. Technology of recreational activities of high school pupils / Natalia Kovalev, Elena Andreeva // Theory and methods of physical education and sports. - 2012. N 2. - P. 29-34

4. Krutsevych $T$. Recreation in physical culture at different groups population / T. Yu. Krutsevych, H. V. Bezverhnya. Kyiv: Olympiyskaya literatura, 2010. - 248 p.

5. Chukhno P. V. Integrated pedagogical approach to the formation of upper secondary enrollment positive motivation to systematic physical training, a healthy lifestyle / P. V. Chukhno, R. R. Azyullyn, E. A. Medvedev // Pedagogicalpsychological and medical-biological problems of physical culture and sports. - Kamsk. - 2010. - N 3. - P. 112118.

6. Ames C. Achivement goals, motivation climate, and motivation progress / C. Ames / / Motivation in sports and exercise. Champaing IL: Human Kinetics. - 1992. - P.161176.

7. Hodge K. Motivation in masters sport: Achievement and social goals / K. Hodge, J. B. Allen, L. Smellie / / Psychology of Sport and Exercise. - 2008. - Vol. 9. - P. 157-176. 